\title{
Mortality among workers receiving compensation awards for silicosis in Ontario 1940-85
}

\author{
M FINKELSTEIN, G M LISS, F KRAMMER, R A KUSIAK \\ From the Health Studies Service, Ontario Ministry of Labour, Toronto, Ontario, Canada M7A 1 T7
}

ABSTRACT The mortality experience of 1190 miners and 289 surface industry workers receiving workers' compensation awards for silicosis in Ontario since 1940 has been studied up to mid-1985. Both groups were found to have a significantly increased mortality from lung cancer (miners' SMR:० 230; surface workers' SMR: 302) and stomach cancer (miners' SMR: 188; surface workers' SMR: 3 366). Adjustment for smoking and country of origin did not explain the excesses observed. The lungf cancer findings are consistent with observations from silicosis registries in Europe. Possible expla- $\bullet$ natory factors are discussed.

The mortality experience of workers receiving compensation awards for silicosis has come under study in recent years. Their life expectancy has been found to be reduced, due largely to deaths from tuberculosis and non-malignant respiratory disease. Early reports from silicosis registries in Sweden ${ }^{1}$ and Ontario ${ }^{2}$ indicating increased mortality from lung cancer among silicotics have been followed by confirmatory studies in Finland ${ }^{3}$ and Italy. ${ }^{4}$ Goldsmith et al suggested that occupational exposure to silica might explain the excess of lung cancer. They hypothesised that silica itself might be a carcinogen, that silica might act as a carrier particle for chemical carcinogens, or that silicosis might be an intermediate pathological state leading to cancer. ${ }^{5}$

The interpretation of occupational data concerning the association between silicosis and cancer is difficult because of confounding by tobacco smoking and the likely presence of diverse carcinogenic agents in the industrial environment. Only the Italian study looked at the question of smoking as a contributory factor. ${ }^{4}$ The objective of the present study was to collect additional information relevant to the assessment of the carcinogenicity of silica by: (1) updating the analysis of the silicotic miners studied previously ${ }^{2}$; (2) enrolling a new group of workers awarded compensation for silicosis attributable to exposure in dusty surface industries; and (3) collecting smoking information for this latter group. Foundry workers were excluded from the cohort because of their exposure to suspected organic carcinogens.

Accepted 29 September 1986
The disease of primary interest was lung cancer but in the light of the report by Kurppa and his colleaguesD of increased rates of stomach cancer among Finnish granite workers ${ }^{6}$ this cause of death was to be tested for an association with silicosis as well. In the presen study a significant excess mortality was observed for. both causes.

\section{Materials and methods}

All the workers in the present study received compensation for disability due to silicosis. Claims for silicosis submitted to the Workers' Compensation $\Phi$ Board (WCB) are assessed by the Advisory Commit $-\stackrel{2}{\vec{\rho}}$ tee on Occupational Chest Diseases, a panel of ur 윽 versity and government physicians that determines, on the basis of radiographic and clinical evidence whether a diagnosis of silicosis may be made and as sesses the degree of disability. A cohort of minerso awarded compensation for silicosis between 1940 and 1976 had previously been assembled from the com- -3 puterised files of the WCB. ${ }^{2}$ A second cohort of surface industry silicotics was identified by searching the records of the advisory committee. Individual files of the latter workers were located and examined for de-으 tails of employment history and smoking habit. Any worker with evidence of malignancy at the time of disability determination was excluded from the co-N hort. Workers were followed up to 30 June 1985 by the use of WCB records. The miners had previouslyo been followed up until 1978, but on extending thew period of follow up it was discovered that the deaths of several dozen miners before 1979 had been missedo because they had not been reported to the WCB section maintaining the silicosis registry. To avoid a re-? 588 
currence of this error, the vital status of all workers presumed alive at the end of follow up was checked against another source of information, the pension payment files. As a result, it is now believed that the assessment of vital status is accurate.

Death certificates were obtained for $115(87 \%)$ of the new deaths among the miners. Of the remaining 17 deaths, information pertaining to the cause was available in WCB files for 12. As indicated in a necropsy report from British Columbia and a report from Finland, two of these deaths were from lung cancer. For the surface workers, death certificates were obtained for $204(96 \%)$ of 212 deaths. Information was available in WCB files for six of the remaining eight deaths; none was attributed to lung or stomach cancer. For those deaths without official certificates, causes of death derived from WCB files were used for categorisation. Any errors in the statistical analysis due to misclassification of these few deaths are expected to be small.

Causes of death were considered in the following broad groupings (with codes from the eighth revision of the International Classification of Diseases): all malignancies (ICD 140-209); lung cancer (162); gastrointestinal (GI) cancer (150-154); stomach cancer (151); non-malignant respiratory diseases including silicosis (460-519); tuberculosis (010-019); and ischaemic heart disease (410-414). Deaths with cause unknown were assigned solely to the all cause category.

To investigate possible trends in time, workers were grouped into four cohorts based on decade of initial disability award. To assess possible differences related to the exposure environment, a classification was also performed by industry type: mining; ceramics and pottery; granite and quarry; silica brick; and others including sandblasting, silica flour, and abrasives. Miners with experience of uranium mining were identified by comparison with the uranium registry assembled for the Ontario Miners Study. ${ }^{\top}$
The mortality experience of the workers with silicosis was compared with that of the general population of Ontario using the person-years method. Age, sex, and time specific Ontario mortality rates were used in combination with the distribution of person-years at risk among the cohorts to determine the "expected" mortality pattern. Tests of statistical significance and calculation of $95 \%$ confidence intervals (CI) were performed by assuming a Poisson distribution of observed deaths.

Information about smoking habits was present in the records of $206(75 \%)$ of the 276 men in the surface industry cohort. Data were not available for the remaining 70 because relevant information had not been recorded or because the clinical files of men dying before 1960 had been destroyed. Because quantitative information about cigarette consumption was of uncertain reliability, a dichotomous classification (ever/never smoker) was used. For comparison with the smoking habits of the general population of Ontario, data were used from the Labour Force Survey collected by Statistics Canada (unpublished).

Because it has been reported that death rates from stomach cancer among immigrants to Canada are greater than the rates among Canadian born residents of Ontario, ${ }^{8}$ information about birthplace was obtained from work histories or death certificates for the surface industry cohort. These data were available for $272(99 \%)$ of the 276 men. Statistical adjustment of SMRs for the effects of smoking and birth place was done by the method suggested by Axelson. ${ }^{9}$

\section{Results}

The original composition of the mining cohorts has already been described. ${ }^{2}$ In 1979 , on entry to this update of the previous study, there were 21 survivors in the 1940-9 cohort, 38 in the 1950-9 cohort, 118 in the $1960-9$ cohort, and 203 in the $1970-5$ cohort. Twenty

Table 1 Description of surface industry cohorts by decade of compensation award and by industry type (men)

\begin{tabular}{|c|c|c|c|c|}
\hline Year of compensation award & No & $\begin{array}{l}\text { Person-years of } \\
\text { observation }\end{array}$ & $\begin{array}{l}\text { Mean age at } \\
\text { compensation }\end{array}$ & $\begin{array}{l}\text { Mean age at } \\
\text { death }\end{array}$ \\
\hline $\begin{array}{l}1940-49 \\
1950-59 \\
1960-69 \\
1970-84\end{array}$ & $\begin{array}{l}38 \\
83 \\
70 \\
85\end{array}$ & $\begin{array}{r}495 \\
1006 \\
711 \\
599\end{array}$ & $\begin{array}{l}55.8 \\
55.8 \\
59.2 \\
56.9\end{array}$ & $\begin{array}{l}68 \cdot 7 \\
67 \cdot 5 \\
69 \cdot 1 \\
66 \cdot 3\end{array}$ \\
\hline Total & 276 & 2811 & $57 \cdot 0$ & $68 \cdot 0$ \\
\hline $\begin{array}{l}\text { Industry type } \\
\text { Ceramics } \\
\text { Granite and quarry } \\
\text { Silica brick } \\
\text { Other }\end{array}$ & $\begin{array}{l}98 \\
76 \\
47 \\
55\end{array}$ & $\begin{array}{r}1097 \\
753 \\
474 \\
487\end{array}$ & $\begin{array}{l}56 \cdot 2 \\
60 \cdot 3 \\
59 \cdot 3 \\
51 \cdot 8\end{array}$ & $\begin{array}{l}67 \cdot 1 \\
70 \cdot 7 \\
69 \cdot 8 \\
62 \cdot 4\end{array}$ \\
\hline Total & 276 & 2811 & $57 \cdot 0$ & $68 \cdot 0$ \\
\hline
\end{tabular}


Table 2 Mortality among miners with silicosis

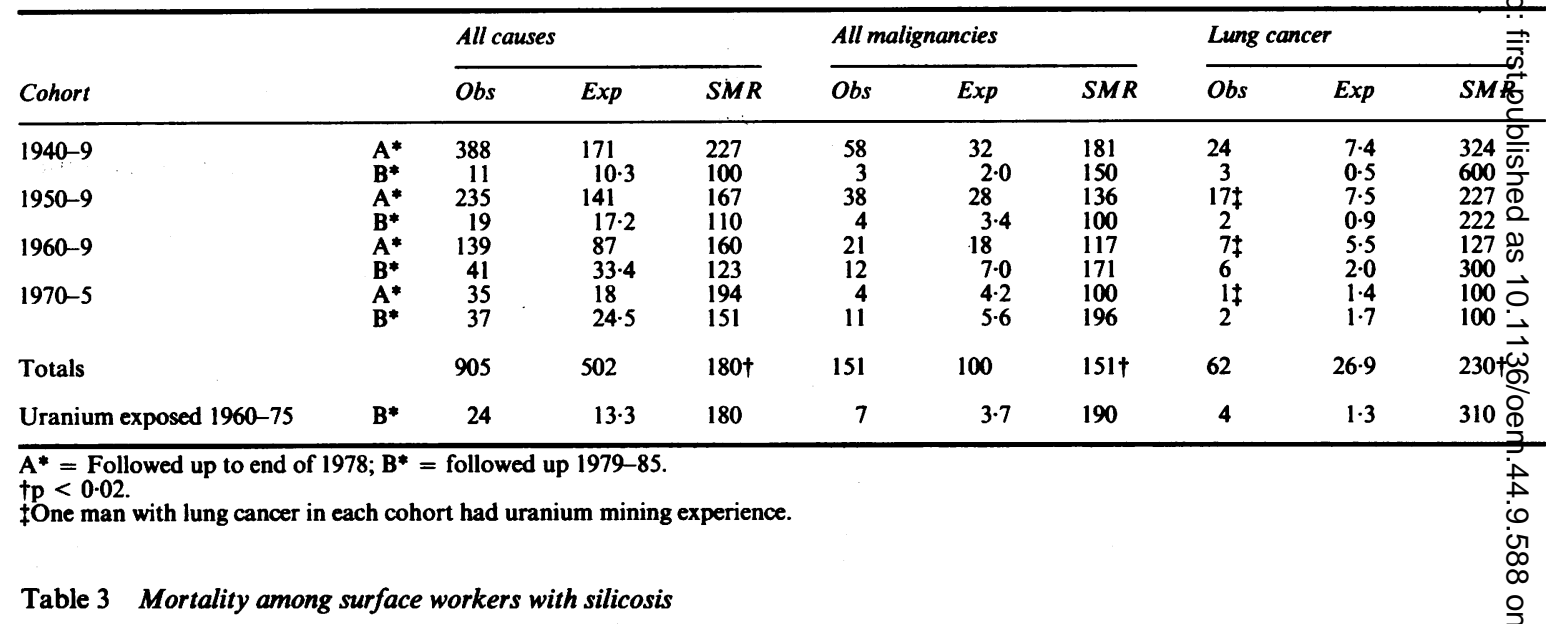

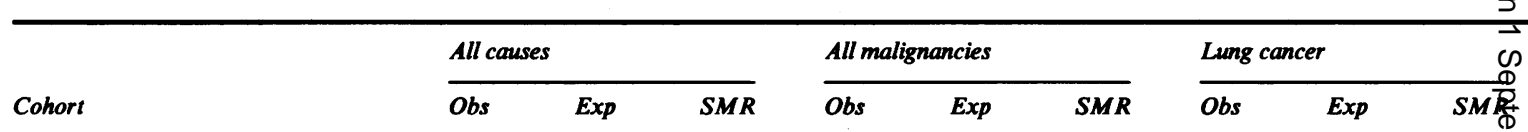

\begin{tabular}{|c|c|c|c|c|c|c|c|c|c|}
\hline Total $(n=276)$ & 206 & $91 \cdot 6$ & $225^{*}$ & 31 & $19 \cdot 5$ & $159 *$ & 16 & $5 \cdot 3$ & \\
\hline Women & 5 & 1.44 & 347 & 3 & 0.5 & 600 & 1 & 0.05 & \\
\hline
\end{tabular}

${ }^{*} \mathrm{p}<0.01$.

Table 4 Mortality among surface workers with silicosis by industry (all time periods combined; men only)

\begin{tabular}{|c|c|c|c|c|c|c|c|c|c|}
\hline \multirow[b]{2}{*}{ Industry } & \multicolumn{3}{|c|}{ All causes } & \multicolumn{3}{|c|}{ All malignancies } & \multicolumn{2}{|c|}{ Lung cancer } & \multirow{2}{*}{$\frac{\frac{2}{\frac{1}{0}}}{S M \frac{\dot{8}}{8}}$} \\
\hline & Obs & $\operatorname{Exp}$ & $S M R$ & Obs & $\operatorname{Exp}$ & $S M R$ & Obs & $\operatorname{Exp}$ & \\
\hline $\begin{array}{l}\text { Silica brick }(n=47) \\
\text { Ceramics }(n=98) \\
\text { Granite and quarry }(n=76) \\
\text { Other }(n=55)\end{array}$ & $\begin{array}{l}35 \\
65 \\
70 \\
36\end{array}$ & $\begin{array}{l}17 \cdot 6 \\
31 \cdot 6 \\
30 \cdot 7 \\
11 \cdot 7\end{array}$ & $\begin{array}{l}199 \\
206 \\
228 \\
309\end{array}$ & $\begin{array}{r}7 \\
7 \\
10 \\
7\end{array}$ & $\begin{array}{l}3 \cdot 8 \\
7 \cdot 0 \\
6 \cdot 1 \\
2 \cdot 6\end{array}$ & $\begin{array}{l}183 \\
100 \\
164 \\
266\end{array}$ & $\begin{array}{l}2 \\
6 \\
5 \\
3\end{array}$ & $\begin{array}{l}1 \cdot 1 \\
2 \cdot 05 \\
1 \cdot 39 \\
0 \cdot 77\end{array}$ & 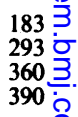 \\
\hline Total $(n=276)$ & 206 & $91 \cdot 6$ & $225^{*}$ & 31 & $19 \cdot 5$ & $159 *$ & 16 & $5 \cdot 3$ & $302 * ?$ \\
\hline
\end{tabular}

*p $<0.01$.

three of the 1960-9 group and 112 of the $1970-5$ cohort had uranium mining experience.

The male cohort from the surface industries is described by decade of compensation award and by industry type in table 1 . In addition, 13 women were followed up for 171 person-years; all but two had worked in ceramics.

\section{MORTALITY EXPERIENCE OF THE MINERS}

Table 2 displays the mortality from selected causes for the mining cohorts. The lines labelled " $A$ " present the revised results of follow up to the end of 1978 , corrected for loss to follow up and deaths missed by the previous analysis. ${ }^{2}$ These additional deaths produced no substantial change in the mortality pattern described earlier.

The lines labelled " $B$ " refer to the additional 6.5 years of follow up from 1 January 1979 to 30 June 1985. Miners who survived to 1979 had, overall, a more favourable experience than that observed in the initial period (A) but mortality was still significantly raised (SMR 126; CI 104-152), primarily attributable 


\begin{tabular}{|c|c|c|c|c|c|c|c|c|c|c|}
\hline \multicolumn{3}{|c|}{ r Stomach cancer } & \multicolumn{2}{|c|}{ Tuberculosis } & \multicolumn{3}{|c|}{ Respiratory disease } & \multicolumn{3}{|c|}{ Ischaemic heart disease } \\
\hline cbs & $\operatorname{Exp}$ & $S M R$ & Obs & $\operatorname{Exp}$ & Obs & $\operatorname{Exp}$ & $S M R$ & Obs & $\operatorname{Exp}$ & $S M R$ \\
\hline $\begin{array}{r}10 \\
0 \\
3 \\
0 \\
2 \\
2 \\
1 \\
1\end{array}$ & $\begin{array}{l}4 \cdot 3 \\
0 \cdot 1 \\
2 \cdot 7 \\
0 \cdot 2 \\
1 \cdot 6 \\
0 \cdot 4 \\
0 \cdot 3 \\
0 \cdot 3\end{array}$ & $\begin{array}{r}233 \\
0 \\
100 \\
0 \\
100 \\
500 \\
100 \\
100\end{array}$ & $\begin{array}{r}101 \\
0 \\
30 \\
2 \\
5 \\
1 \\
1 \\
0\end{array}$ & $\begin{array}{l}1.08 \\
0.01 \\
0.49 \\
0.01 \\
0.20 \\
0.02 \\
0.01 \\
0.01\end{array}$ & $\begin{array}{r}113 \\
5 \\
70 \\
7 \\
46 \\
12 \\
10 \\
11\end{array}$ & $\begin{array}{r}9.9 \\
1.1 \\
10.2 \\
1.8 \\
7.2 \\
3.3 \\
1.4 \\
2.3\end{array}$ & $\begin{array}{r}1140 \\
455 \\
686 \\
389 \\
639 \\
364 \\
714 \\
478\end{array}$ & $\begin{array}{r}57 \\
2 \\
45 \\
2 \\
6 \\
4 \\
9 \\
6\end{array}$ & $\begin{array}{c}72 \\
3 \cdot 7 \\
59 \\
6 \cdot 2 \\
8 \cdot 7 \\
12 \cdot 1 \\
7.0 \\
8.9\end{array}$ & $\begin{array}{r}79 \\
5 \\
76 \\
32 \\
69 \\
33 \\
129 \\
67\end{array}$ \\
\hline 19 & $10 \cdot 1$ & $188 \dagger$ & 140 & 1.83 & 274 & $37 \cdot 2$ & $737 \dagger$ & 131 & 178 & 74 \\
\hline 0 & $0 \cdot 2$ & 0 & 0 & 0.01 & 6 & 0.8 & $7 \cdot 5$ & 2 & $4 \cdot 8$ & 42 \\
\hline
\end{tabular}

\begin{tabular}{|c|c|c|c|c|c|c|c|c|c|c|}
\hline \multicolumn{3}{|c|}{ Stomach cancer } & \multicolumn{2}{|c|}{ Tuberculosis } & \multicolumn{3}{|c|}{ Respiratory disease } & \multicolumn{3}{|c|}{ Ischaemic heart disease } \\
\hline Obe & $\operatorname{Exp}$ & $S M R$ & Obs & $\operatorname{Exp}$ & Obs & $\operatorname{Exp}$ & $S M R$ & Obs & $\operatorname{Exp}$ & $S M R$ \\
\hline $\begin{array}{l}3 \\
2 \\
2 \\
0\end{array}$ & $\begin{array}{l}0.47 \\
0.70 \\
0.46 \\
0.28\end{array}$ & $\begin{array}{r}638 \\
286 \\
435 \\
0\end{array}$ & $\begin{array}{r}11 \\
8 \\
5 \\
0\end{array}$ & $\begin{array}{l}0.16 \\
0.14 \\
0.06 \\
0.02\end{array}$ & $\begin{array}{r}8 \\
27 \\
15 \\
10\end{array}$ & $\begin{array}{l}0.96 \\
2.0 \\
1.9 \\
1.2\end{array}$ & $\begin{array}{r}833 \\
1350 \\
789 \\
833\end{array}$ & $\begin{array}{r}8 \\
12 \\
19 \\
9\end{array}$ & $\begin{array}{r}7 \cdot 3 \\
13 \cdot 5 \\
10 \cdot 3 \\
6 \cdot 4\end{array}$ & $\begin{array}{r}110 \\
89 \\
184 \\
141\end{array}$ \\
\hline 7 & 1.9 & $366^{*}$ & 24 & 0.38 & 60 & $6 \cdot 0$ & $984^{*}$ & 48 & $37 \cdot 5$ & 128 \\
\hline 0 & 0.02 & 0 & 0 & 0.06 & 0 & 0 & $\mathbf{0}$ & 0 & 0.37 & $\mathbf{0}$ \\
\hline
\end{tabular}

\begin{tabular}{|c|c|c|c|c|c|c|c|c|c|c|}
\hline \multicolumn{3}{|c|}{ Stomach cancer } & \multicolumn{2}{|c|}{ Tuberculosis } & \multicolumn{3}{|c|}{ Respiratory disease } & \multicolumn{3}{|c|}{ Ischaemic heart disease } \\
\hline Obs & $\operatorname{Exp}$ & $S M R$ & Obs & $\operatorname{Exp}$ & Obs & $\operatorname{Exp}$ & $S M R$ & Obs & $\operatorname{Exp}$ & $S M R$ \\
\hline $\begin{array}{l}2 \\
1 \\
2 \\
2\end{array}$ & $\begin{array}{l}0.35 \\
0.62 \\
0.69 \\
0.25\end{array}$ & $\begin{array}{l}571 \\
161 \\
290 \\
800\end{array}$ & $\begin{array}{l}5 \\
9 \\
7 \\
3\end{array}$ & $\begin{array}{l}0.06 \\
0.12 \\
0.15 \\
0.05\end{array}$ & $\begin{array}{r}8 \\
15 \\
24 \\
13\end{array}$ & $\begin{array}{l}1 \cdot 2 \\
2 \cdot 1 \\
2 \cdot 0 \\
0.8\end{array}$ & $\begin{array}{r}667 \\
714 \\
1200 \\
1625\end{array}$ & $\begin{array}{r}3 \\
22 \\
16 \\
7\end{array}$ & $\begin{array}{r}7 \cdot 2 \\
12.8 \\
12 \cdot 8 \\
4.7\end{array}$ & $\begin{array}{r}42 \\
172 \\
125 \\
149\end{array}$ \\
\hline 7 & 1.91 & $366^{*}$ & 24 & 0.4 & 60 & $6 \cdot 1$ & $984 \dagger$ & 48 & $37 \cdot 5$ & 128 \\
\hline
\end{tabular}

to deaths from non-malignant respiratory diseases, and cancer. Mortality from lung cancer (13 observed, $5 \cdot 1$ expected, SMR 255; CI 136-436) and stomach cancer ( 3 observed, 1 expected) were both raised. Combined results from both follow up periods show a significant excess of both lung (SMR 230; CI 178-297) and stomach (SMR 188; CI 120-290) cancers. Deaths from colonic and rectal cancers were fewer than expected so that overall gastrointestinal cancer rates were not raised.

Three of the 49 men dying of lung cancer before
1979 had uranium mining experience; they were estimated to have had cumulative exposures to radon daughter decay products of 10,29 , and 126 working level months. The mortality pattern from 1979 to 1985 of all men with uranium mining experience compensated during $1960-75$ is presented separately at the bottom of table 2 .

\section{MORTALITY EXPERIENCE OF SURFACE INDUSTRY} WORKERS

Table 3 shows the mortality among the surface work- 
Table 5 Smoking habits among surface workers with silicosis

\begin{tabular}{|c|c|c|c|c|}
\hline Compensation cohort & No of men & No with habits known & Never smokers & Current and former smokers \\
\hline $\begin{array}{l}1940-49 \\
1950-59 \\
1960-69 \\
1970-84\end{array}$ & $\begin{array}{l}38 \\
83 \\
70 \\
85\end{array}$ & $\begin{array}{r}8(21 \%) \\
53(64 \%) \\
61(87 \%) \\
84(99 \%)\end{array}$ & $\begin{array}{l}0 \\
11(20 \cdot 8 \%) \\
7(11 \cdot 5 \%) \\
13(15 \cdot 5 \%)\end{array}$ & $\begin{array}{c}8(100 \%) \\
42(79 \cdot 2 \%) \\
54(88 \cdot 5 \%) \\
71(84 \cdot 5 \%)\end{array}$ \\
\hline Totals & 276 & $206(74 \cdot 6 \%)$ & $31(15 \%)$ & $175(85 \%)$ \\
\hline
\end{tabular}

ers for selected causes, by decade of compensation. All cause mortality was consistently about twice that expected, largely arising from excess deaths from tuberculosis and non-malignant respiratory diseases. In addition, a statistically significant excess of deaths due to malignancies $(p<0.01)$ was found. This was accounted for by excess deaths due to lung cancer (SMR 302; CI 173-489) and stomach cancer (SMR 366; CI 147-754). Deaths due to colonic and rectal cancers were the same as expected ( 3 observed, 2.94 expected). The five deaths occurring among the women in the cohort exceeded expectation (table 3); one death was due to lung cancer in a ceramics worker.

A similar pattern was observed when the mortality experience was examined by industry type (table 4), when a consistent excess of deaths due to lung cancer was seen in each industry.

Information on cigarette smoking was available from WCB records for $206(75 \%)$ of the surface cohort and indicated that $15 \%$ were never-smokers (table 5). There was no substantial variation in habit by decade of birth or decade of compensation. Of those alive in 1975, 20\% were never smokers. By comparison, Ontario statistics for 1975 indicate that the proportions of never smokers among men aged 45 to 64 , and 65 and over were $23 \%$ and $33 \%$, respectively (Statistics Canada, unpublished data).

Information about birth place was available for 272 $(99 \%)$ of the male surface workers and showed that $52 \%$ were born outside Canada compared with $33.9 \%$ of Ontario residents (men aged 45 and over) in $1971 .{ }^{10}$ There were increased proportions in our cohort of workers from countries with high rates of stomach cancer. In particular, $25 \%$ were born in the United Kingdom and $10 \%$ in Italy compared with $12.2 \%$ and $5.6 \%$, respectively, for the male population of Ontario.

\section{Discussion}

Workers on the rolls of silicosis registries in six jurisdictions in Canada (this study) and Europe $e^{1341112}$ have increased rates of lung cancer by comparison with regional or national populations. Although criteria for inclusion in the registries may have differed, one may reasonably conclude that an association exists between certification for silicosis and increas $\overline{\text { gd }}$ risk of lung cancer. The reasons for this association remain unclear.

When studying lung cancer, the first factor thăt must be considered is tobacco smoking. Silicosis rẹgistries might contain an increased proportion $4 . \mathrm{f}$ smokers because blue collar workers may smoke more heavily than the general population, smokiog may increase the chance of developing silicosis interfering with clearance mechanisms, or becausse smoking related respiratory symptoms may incresse the likelihood of certification for silicosis. In te present investigation of silicotic surface workers 15 of those with known smoking habits were reported甲o be "never smokers" compared with about $30 \%$ in the general population of Ontario. In the Veneto regogsey in Italy only $13 \%$ were non-smokers, a propostion believed to be lower than that in the Veneto regon Might the overrepresentation of smokers in the cohorts account for the more than doubled risk $\overline{\Phi f}$ lung cancer?

The appendix shows a calculation in which a luक्षg cancer risk factor of 20 was assumed for ever smok $\overrightarrow{\text { rits }}$ versus never smokers. This calculation indicates that a $20 \%$ increased risk might be expected among cohort of silicotics because of the difference in smo ing prevalence. Blair et al compared crude and smaking adjusted lung cancer SMRs for selectid occupational groups within a large cohort of United States veterans and found that adjustment for smọing generally resulted in a change of less than $30 \%{ }^{3}$ It is concluded that differences in smoking habit alo are unlikely to account for the magnitude of increased risk of lung cancer observed in the regist5y studies.

Concurrent exposure to silica might, howevi increase the risk from smoking. There is experimeneal support for this hypothesis. Niemeier ${ }^{14}$ ahd Stenback ${ }^{15}$ both treated hamsters with intratrach instillations of silica, benzo(a)pyrene (BaP), or BaP plus silica. Whereas silica produced no respiratey tumours, combined exposure to $\mathrm{BaP}$ and silica ptoduced significantly more tumours than $\mathrm{BaP}$ alofe. Exposure to silica may have increased the dose of Ba्P by adsorption on to the surface of the crystals or $\bar{Q}$. 
altering its clearance. $\mathrm{BaP}$ and other organic carcinogens are present in tobacco smoke and the same effect may occur in people.

In addition to tobacco smoke, workers with silicosis may have been exposed to other carcinogens. Since foundry workers are believed to be exposed to various carcinogens, they were deliberately omitted from this study, but in other studies lung cancer SMRs for foundry workers have not differed substantially from those of silicotics from other industrial settings. ${ }^{13}$ In the present study silica brick workers may have had some exposure to carcinogens but the lung cancer SMR (based on small numbers) was similar to the average. In general, in registry studies the risk has been similar across occupational groupings so that if the increased risk is not due to smoking, silica, or silicosis, various similarly acting confounding exposures would have to be invoked in explanation.

Goldsmith et al proposed that silica itself might be a carcinogen or that the fibrotic process might be an intermediate stage on the way to cancer. ${ }^{5}$ Several experiments provide data in support of these hypotheses. Hesterberg et al found that silica induced cytogenetic changes and morphological transformation of Syrian hamster embryo cells in culture, a preneoplastic change produced by exposure to a wide variety of physical and chemical carcinogens. ${ }^{16}$ They observed that silica was readily taken up by these cells and accumulated in the perinuclear region, suggesting that chromosomal interaction could occur, especially during mitosis when the nuclear membrane disappears.

In animal studies lung tumours were produced in two strains of rats administered silica intratracheally ${ }^{1718}$ and in Fischer 344 rats exposed to silica concentrations of 50 and $12 \mathrm{mg} / \mathrm{m}^{3}$ in inhalation chambers. ${ }^{1719}$ Lymphomas have also been induced in Wistar rats after intrapleural injection of silica. ${ }^{20}$ By contrast with these observations in rats, investigators have been unable to produce silica induced tumours in hamsters. Saffiotti noted that another difference between these species in their response to silica is that rats develop fibrosis but hamsters do not. ${ }^{21}$

Quartz is thus a carcinogen in rats. What is the human evidence? Unfortunately, in most occupations in which there is substantial exposure to silica, concurrent exposure to other agents confounds the interpretation of any silica-cancer association. Miners, for example, may be exposed to radon daughters, fibres, or trace elements such as aresenic, whereas foundry workers may be exposed to polycyclic aromatic hydrocarbons. The quarry and granite industry is the one in which workers are likely to have the least exposure to other agents. Silicotics from this industry in the Ontario, Finnish, ${ }^{3}$ and Italian ${ }^{4}$ registries have had increased rates of lung cancer. On the other hand, a proportional mortality (PMR) study of Swiss silicotics found no increase in deaths from lung cancer in stone workers. ${ }^{11}$

There have been two PMR studies of granite workers in the United States. Davis et al studied mortality in the Vermont granite industry. ${ }^{22}$ A small excess $(20 \%)$ of lung cancer was observed, but there was no apparent dose-response relation. Steenland and Beaumont found a similar excess of lung cancer among members of the Granite Cutters Union. ${ }^{23}$ No relation with duration of union membership was found, but men dying of lung cancer were more likely to have silicosis mentioned on the death certificate than men dying of other cancers.

Excess deaths from stomach cancer were observed in both the miners and surface industry workers in the Ontario cohort. There are associations between birth place, ${ }^{8}$ tobacco smoking, ${ }^{24}$ and stomach cancer. There was an overrepresentation in this cohort of smokers and of individuals from countries with high mortality from stomach cancer, but adjustments for these factors similar to the one shown in the appendix were unable to account for the magnitude of the excess.

An association between stomach cancer and exposure to silica has not been consistently observed. Kurppa et al reported an excess of stomach cancer in a group of Finnish quarry workers ${ }^{6}$ but did not present a stomach cancer SMR in the Finnish registry study $^{3}$ (the gastrointestinal cancer SMR was not raised). Fewer deaths from stomach cancer than expected were found in the Italian registry ${ }^{4}$ but stomach cancer mortality was significantly raised among dust exposed workers in Vienna. ${ }^{12}$ Excess stomach cancer was observed among gold miners in Ontario ${ }^{7}$ but there was a deficit among gold miners in the United States. ${ }^{25}$ It is not yet possible to account for these discrepant findings.

In summary, a consistent excess of lung cancer has been found in studies of silicosis registries in Canada and Europe. The reasons for this association are still unclear. All these workers were exposed to silica and developed silicosis but many had concurrent occupational exposures to other agents and most were cigarette smokers. Further study of the health experience of silica exposed populations, preferably in a setting in which dose-response relations can be investigated, would be helpful in evaluating the part that silica plays in this association.

\section{Appendix}

ADJUSTMENT OF "EXPECTED" LUNG CANCERS

FOR DIFFERENCES IN SMOKING HABIT

The population of surface industry silicotics consisted 
of never smokers plus a mixture of current and former smokers. Assume that the lung cancer risk factor for ever smokers compared with never smokers is 20 . One may then compare the risks between populations containing $15 \%$ (this cohort) and $30 \%$ (general population) never smokers respectively, using the method of Axelson ${ }^{9}$

$$
I=I_{C F} \times P_{C F}+I_{0}\left(1-P_{C F}\right)
$$

where

$$
\begin{aligned}
I= & \text { overall incidence (deaths) of lung cancer } \\
I_{C F}= & \text { incidence as caused by the confounding } \\
& \text { factor (smoking) } \\
P_{C F}= & \text { proportion of population with the fac- } \\
& \text { tor in question (smokers) } \\
I_{0}= & \text { incidence among those without the risk } \\
& \text { factors (never smokers) }
\end{aligned}
$$

If the effect of the confounding factor is known (here $R=20$ is chosen) the formula may be rewritten as:

$$
\mathrm{I}=\mathrm{RI}_{0} \times \mathrm{P}_{\mathrm{CF}}+\mathrm{I}_{0}\left(1-\mathrm{P}_{\mathrm{CF}}\right) \text {. }
$$

Therefore in the general population

$$
\begin{aligned}
\mathrm{I}_{\mathrm{G}} & =(20)\left(\mathrm{I}_{0}\right)(0 \cdot 7)+\mathrm{I}_{0}(0 \cdot 3) \\
& =14 \cdot 3 \mathrm{I}_{0}
\end{aligned}
$$

In the study population

$$
\begin{aligned}
I_{S} & =(20)\left(I_{0}\right)(0 \cdot 85)+I_{0}(0 \cdot 15) \\
& =17 \cdot 2 I_{0}
\end{aligned}
$$

Therefore the relative risk in the study population due to a greater prevalence of smokers is

$$
\frac{I_{S}}{I_{G}}=\frac{17 \cdot 2}{14 \cdot 3}=1 \cdot 2 \text {. }
$$

We thank Ms Lisa Fiorello of the Workers' Compensation Board for help with the follow up of the miners. Ms Brenda Crysler typed this report.

\section{References}

1 Westerholm P. Silicosis. Observations on a case register. Scand J Work Environ Health 1980;6 (suppl 2):1-86.

2 Finkelstein MM, Kusiak RA, Suranyi G. Mortality among miners receiving workmen's compensation for silicosis in Ontario: 1940-1975. J Occup Med 1982;24:663-7.

3 Kurppa K, Gudbergsson H, Hannunkari I, et al. Lung cancer among silicotics in Finland. In: Goldsmith DF, Winn DM, Shy CM, eds. Silica, silicosis, and cancer. New York: Praeger, 1986:311-9.

4 Zambon P, Simonato L, Mastrangelo G, et al. A mortality study of workers compensated for silicosis during 1959 to 1963 in the Veneto region of Italy. In: Goldsmith DF, Winn DM, Shy CM, eds. Silica, silicosis, and cancer. New York: Praeger, 1986: $367-4$.

5 Goldsmith DF, Guidotti TL, Johnston DR. Does occupational exposure to silica cause lung cancer? Am $J$ ind $M$ 1982;3:423-40.

6 Kurppa K, Koskela RS, Gudbergsson H. Gastrointestinal cancei in workers exposed to quartz. Lancet 1982;ii:150.

7 Muller J, Wheeler WC, Gentleman JF, Suranyi G, Kusiak Study of mortality of Ontario miners. In: Stocker H, ed Occupational radiation safety in mining. Toronto: Canadiafl Nuclear Association 1985:335-43.

8 Newman AM, Spengler RF. Cancer mortality among immigram populations in Ontario, 1969 through 1973. Can Med Assoc 9 1984;130:399-405.

9 Axelson O. Aspects of confounding in occupational health epidemiology. Scand J Work Environ Health 1978;4:85-8.

10 Statistics Canada. 1971 census of Canada. Vol 1, pt 4. Populatio $\overrightarrow{\vec{n}_{n}}$ catalogue 92-737. Ottawa, Statistics Canada, 1974.

11 Schuler G, Ruttner JR. Silicosis and lung cancer in Switzerlan\& In: Goldsmith DF, Winn DM, Shy CM, eds. Silica, silicosi and cancer. New York: Praeger, 1986:357-66.

12 Neuberger M, Kundi M, Westphal G, Grundorfer W. This Viennese dusty worker study. In: Goldsmith DF, Winn DNA Shy CM, eds. Silica, silicosis and cancer. New York: Praegê 1986:415-22.

13 Blair A, Hoar SK, Walrath J. Comparison of crude and smokingo adjusted standardized mortality ratios. J Occup Med 1989 27:881-4.

14 Niemeier RW, Mulligan LT, Rowland J. Cocarcinogenicity of foundry silica sand in hamsters. In: Goldsmith DF, Winn DND Shy CM, eds. Silica, silicosis and cancer. New York: Praegep 1986:215-28.

15 Stenback F, Wasenius VM, Rowland J. Alveolar and interstiti changes in silicate-associated lung tumors in Syrian hamsters In: Goldsmith DF, Winn DM, Shy CM, eds. Silica, silicosis and cancer. New York: Praeger, 1986:199-214.

16 Hesterberg TW, Oshimura M, Brody AR, Barrett JC. Asbeg్తిto@ and silica induce morphological transformation of mamma ian

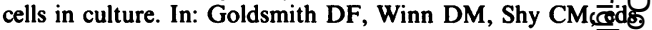
Silica, silicosis and cancer. New York: Praeger, 1986:177-10

17 Holland LM, Wilson JS, Tillery MI, Smith DM. Lung cancer rats exposed to fibrogenic dusts. In: Goldsmith DF, Winn DM Shy CM, eds. Silica, silicosis and cancer. New York: Praege? 1986:267-80.

18 Groth DH, Stettler LE, Platek SF, Lal JB, Burg JR. Lung tumo \& in rats treated with quartz by intratracheal instillation. IR Goldsmith DF, Winn DM, Shy CM, eds. Silica, silicosis and cancer. New York: Praeger, 1986:243-54.

19 Dagle GE, Wehner AP, Clark ML, Buschbom RL. Chronfe inhalation exposure of rats to quartz. In: Goldsmith DF, Wing DM, Shy CM, eds. Silica, silicosis and cancer. New York Praeger, 1986:255-66.

20 Wagner MMF, Wagner JC. Lymphomas in the Wistar rat aftep intrapleural inoculation of silica. JNCI 1972;49:81-91.

21 Saffiotti U. The pathology induced by silica in relation to fibrogenesis and carcinogenesis. In: Goldsmith DF, Winn DN? Shy CM, eds. Silica, silicosis and cancer. New York: Praege?, 1986:287-310.

22 Davis LK, Wegman DH, Monson RR, Froines J. Mortaliey experience of Vermont granite workers. Am J Ind Meses 1983;4:705-23.

23 Steenland K, Beaumont J. A proportionate mortality study $\overline{\overline{\phi 6}}$ granite cutters. Am J Ind Med 1986;9:189-201.

24 Surgeon General. The health consequences of smoking. Cancen Rockville: US Department of Health and Human Service? 1982:132-7.

25 Brown DP, Kaplan SD, Zumwalde RD, Kaplowitz M, Archळ్ VE. Retrospective cohort mortality study of underground gold mine workers. In: Goldsmith DF, Winn DM, Shy CM, eds. Silica, silicosis and cancer. New York: Praeger, 1986:335-50 